\title{
CHARACTERIZATION OF ITURIN A IN ANTIBIOTICS FROM VARIOUS STRAINS OF BACILLUS SUBTILIS
}

\author{
Françoise Besson, Françoise Peypoux, Georges Michel \\ and Lucien Delcambe* \\ Laboratoire de Biochimie Microbienne, Université Claude Bernard \\ Lyon I, 43 Boulevard du 11 Novembre 1918, 69621 Villeurbanne, France \\ * Centre National de Production, et d'Etude des Substances, d'Origine Microbienne (C.P.E.M.) \\ 32, Boulevard de la Constitution, 4000 Liège, Belgique \\ (Received for publication May 17, 1976)
}

\begin{abstract}
Iturin A, an antifungal lipopeptide characterized by the presence of homologous liposoluble $\beta$-aminoacids was found to be the active component to bacillomycin $\mathbf{B}$, bacillomycin $\mathbf{R}$ and eumycin. Iturin $\mathbf{A}$ was identified by thin-layer chromatography, aminoacid analysis and by characterization of liposoluble aminoacids and peptides. Another two preparations: the antibiotic of RAUBITSCHEK and the bacillomycin of LANDY et al. contain components of the same structural type but they are different from iturin A.
\end{abstract}

Several antibiotics are produced by bacteria of the genus Bacillus and many of them have a polypeptide structure. ${ }^{1)}$ In particular, crude or partially purified preparations isolated from cultures of Bacillus subtilis are primarily active against fungi and weakly or not active against bacteria. Such an antibiotic is iturin, isolated by DeLCAMBE ${ }^{2)}$. From a purified preparation we isolated iturin A with high antifungal activity and we determined its structure ${ }^{3 \sim 5)}$.

We studied another antibiotic from Bacillus subtilis: mycosubtilin, isolated by WALTON and WoODRUFF $^{\text {() }}$ and we determined its structure. ${ }^{7)}$ The methods of purification developed in our previous work were used for the purification of some other substances produced by several strains of Bacillus subtilis.

The names of these antibiotics are often ambiguous and we used the nomenclature of SHARON et al. ${ }^{8)}$ : bacillomycin $\mathrm{B}^{\text {9) }}$, bacillomycin $\mathrm{R}^{10)}$, eumycin ${ }^{11}$, the antibiotic of RAUBITSCHEK ${ }^{12)}$ and the bacillomycin of LANDY et al. ${ }^{13)}$ Previous gas chromatographic identification of $\beta$-aminoacids in the crude preparations of these substances in conjunction with the high antifungal activity similar to that of iturin suggests the presence of iturin.

This paper reports the results of our investigations in this matter.

\section{Antimicrobial Activities of Crude Preparations}

The crude preparations of antibiotics were obtained from 500 liters of culture medium (see experimental part). The antimicrobial activity of these preparations was tested on various microorganisms by a cylinder agar plate diffusion method. No activity was detected with Bacillus subtilis, Bacillus cereus, Staphylococcus aureus, Streptomyces griseoflavus, Streptomyces R 61, Actinomadura R 39, Mycobacterium smegmatis, Serratia marcescens, Azotobacter vinelandii, Aerobacter aerogenes, Proteus vulgaris, Escherichia coli B, Benekea harveyi, Flavobacterium dehydrogenans; a weak activity was noticed with Agrobacterium tumefaciens whereas Penicillium notatum and Penicillium chrysogenum were strongly inhibited. Similar results were obtained by serial tube dilution method in nutrient broth as reported 
Table 1. Antimicrobial activities of antibiotic preparations from Bacillus subtilis measured by the serial tube dilution method.

\begin{tabular}{|c|c|c|c|c|c|c|}
\hline \multirow{2}{*}{ Test organisms } & \multicolumn{6}{|c|}{ Antibiotic preparation } \\
\hline & Iturin & $\begin{array}{c}\text { Bacillomycin } \\
\text { B }\end{array}$ & ${ }_{\mathrm{R}}^{\text {Bacillomycin }}$ & Eumycin & $\begin{array}{l}\text { Antibiotic of } \\
\text { RAUBITSCHEK }\end{array}$ & Mycosubtilin \\
\hline Staphylococcus aureus & - & - & - & - & - & - \\
\hline Bacillus subtilis & - & - & - & - & - & - \\
\hline Mycobacterium smegmatis & + & - & - & - & - & - \\
\hline Agrobacterium tumefaciens & + & + & H & - & - & - \\
\hline Azotobacter vinelandii & - & - & - & + & - & + \\
\hline Flavobacterium dehydrogenans & - & - & - & - & - & - \\
\hline Benekea harveyi & + & - & - & - & - & + \\
\hline Penicillium chrysogenum & HI & + & + & + & \# & m \\
\hline Penicillium notatum & H & + & + & + & H & WH \\
\hline
\end{tabular}

MIC: $H=$ from 5 to $10 \mu \mathrm{g} / \mathrm{ml} ; \quad H=$ from 10 to $50 \mu \mathrm{g} / \mathrm{ml} ; \quad+=$ from 50 to $150 \mu \mathrm{g} / \mathrm{ml}$; $-=$ over $150 \mu \mathrm{g} / \mathrm{ml}$.

in Table 1 .

In this assay, the apparent differences of activity observed with the several antibiotics must be attributed to their different levels of purification: mycosubtilin was pure, iturin was purified to some extent and the other substances were poorly purified. However, when the tests of activity were performed on highly purified iturin and iturin containing substances, similar activities were found (Table $5)$.

In both types of assays, the crude antibiotic preparations tested had poor or no antibacterial activity and a typical activity against Penicillia strains. Such an activity was observed previously with iturin and mycosubtilin.

\section{Purification of Active Compound}

Crude antibiotic preparations were dissolved in methanol $(0.2 \mathrm{~g} / \mathrm{ml})$ and purified by precipitation with acetone. The addition of 6 volumes of acetone gave a pigmented precipitate which was discarded, a further addition of 6 volumes of acetone gave another precipitate which was collected by centrifugation. This insoluble part was purified by column chromatography on Sephadex LH 20 with the solvent: hexane - chloroform - methanol (25: 45: 10).

The fractions were collected and tested by thin-layer chromatography on silica gel. Their antifungal activity was tested on Penicillium chrysogenum; the results are shown in Table 2.

Active fractions of bacillomycin B, bacillomycin R and eumycin have similar elution volumes but the active fraction of the antibiotic of RAUBITSCHEK had a very different elution volume. These fractions were further purified by column chromatography on silicic acid with the solvent system: chloroform - methanol - water $(65: 25: 4)$ and the compound was tested by thin-layer chromatography on silica gel 60 for comparison with iturin A, mycosubtilin and bacillomycin of LANDY et al. (Table 3).

Table 3 shows that the Rf of bacillomycin B, bacillomycin R, eumycin and iturin A are identical, the $\mathrm{Rf}$ of the antibiotic of RAUBITSCHEK and of the bacillomycin of LANDY et al. is different from the $\mathrm{Rfs}$ of iturin A and of mycosubtilin. 
Table 2. Antifungal activity of the fractions obtained from column chromatography of antibiotic preparations on Sephadex LH 20.

\begin{tabular}{|c|c|c|c|c|c|c|c|}
\hline & & \multirow{2}{*}{$\begin{array}{l}\text { Elution } \\
\text { volume }\end{array}$} & \multicolumn{5}{|c|}{ Concentrations (mg/ml) } \\
\hline & & & 0.05 & 0.25 & 0.5 & 1 & 5 \\
\hline $\begin{array}{l}\text { Bacillomycin } \mathrm{B} \\
\text { crude preparation }\end{array}$ & $\begin{array}{l}\text { Fraction } \mathrm{B}_{1} \\
\text { Fraction } \mathrm{B}_{2} \\
\text { Fraction } \mathrm{B}_{3} \\
\text { Fraction } \mathrm{B}_{4}\end{array}$ & $\begin{array}{c}70 \mathrm{ml} \\
150 \mathrm{ml} \\
250 \mathrm{ml} \\
\text { methanol }\end{array}$ & $\begin{array}{l}- \\
+ \\
- \\
-\end{array}$ & $\begin{array}{l}- \\
+ \\
- \\
-\end{array}$ & $\begin{array}{l}- \\
H \\
- \\
-\end{array}$ & $\begin{array}{l}- \\
H \\
- \\
-\end{array}$ & $\begin{array}{l}H \\
- \\
H \\
- \\
-\end{array}$ \\
\hline $\begin{array}{l}\text { Bacillomycin } \mathrm{R} \\
\text { crude preparation }\end{array}$ & $\begin{array}{l}\text { Fraction } \mathrm{R}_{1} \\
\text { Fraction } \mathrm{R}_{2} \\
\text { Fraction } \mathrm{R}_{3}\end{array}$ & $\begin{array}{r}70 \mathrm{ml} \\
155 \mathrm{ml} \\
235 \mathrm{ml}\end{array}$ & $\begin{array}{l}- \\
- \\
-\end{array}$ & $\begin{array}{l}- \\
- \\
-\end{array}$ & $\begin{array}{l}- \\
+ \\
-\end{array}$ & $\begin{array}{l}- \\
+ \\
+\end{array}$ & $\begin{array}{l}H \\
- \\
H \\
H\end{array}$ \\
\hline $\begin{array}{l}\text { Eumycin } \\
\text { crude preparation }\end{array}$ & $\begin{array}{l}\text { Fraction } \mathrm{E}_{1} \\
\text { Fraction } \mathrm{E}_{2} \\
\text { Fraction } \mathrm{E}_{3} \\
\text { Fraction } \mathrm{E}_{4}\end{array}$ & $\begin{array}{c}70 \mathrm{ml} \\
185 \mathrm{ml} \\
385 \mathrm{ml} \\
\text { methanol }\end{array}$ & $\begin{array}{l}- \\
+ \\
- \\
-\end{array}$ & $\begin{array}{l}- \\
H \\
- \\
-\end{array}$ & $\begin{array}{l}- \\
H \\
- \\
-\end{array}$ & $\begin{array}{l}- \\
H \\
- \\
-\end{array}$ & $\begin{array}{l}H \\
- \\
H \\
+ \\
-\end{array}$ \\
\hline $\begin{array}{l}\text { Antibiotic of } \\
\text { RAUBITSCHEK } \\
\text { crude preparation }\end{array}$ & $\begin{array}{l}\text { Fraction } \mathrm{SR}_{1} \\
\text { Fraction } \mathrm{SR}_{2} \\
\text { Fraction } \mathrm{SR}_{3} \\
\text { Fraction } \mathrm{SR}_{4} \\
\text { Fraction } \mathrm{SR}_{5} \\
\text { Fraction } \mathrm{SR}_{8}\end{array}$ & $\begin{array}{c}70 \mathrm{ml} \\
150 \mathrm{ml} \\
215 \mathrm{ml} \\
385 \mathrm{ml} \\
665 \mathrm{ml} \\
\text { methanol }\end{array}$ & $\begin{array}{l}- \\
- \\
- \\
- \\
- \\
-\end{array}$ & $\begin{array}{l}- \\
- \\
- \\
- \\
- \\
-\end{array}$ & $\begin{array}{l}- \\
- \\
- \\
- \\
- \\
+\end{array}$ & $\begin{array}{l}- \\
- \\
- \\
- \\
- \\
H\end{array}$ & $\begin{array}{l}H \\
- \\
- \\
- \\
- \\
- \\
H\end{array}$ \\
\hline
\end{tabular}

Agar plate diffusion method, + means diameters of the zone of inhibition $<15 \mathrm{~mm},+>15 \mathrm{~mm}$.

Table 3. Rf of purified antibiotics from various crude preparations on silica gel 60 plates.

\begin{tabular}{|c|c|c|c|}
\hline \multirow[b]{2}{*}{ Antibiotic } & \multicolumn{3}{|c|}{ Solvents } \\
\hline & $\begin{array}{l}\text { Chloroform - methanol - } \\
\text { water }(65: 25: 4)\end{array}$ & $\begin{array}{l}\text { Butanol - acetic acid - } \\
\text { water }(65: 10: 25)\end{array}$ & $\begin{array}{l}\text { Butanol - acetone - } \\
\text { water }(16: 24: 4)\end{array}$ \\
\hline Bacillomycin $\mathbf{B}$ & 0.35 & 0.28 & 0.53 \\
\hline Bacillomycin $\mathrm{R}$ & 0.35 & 0.28 & 0.53 \\
\hline Eumycin & 0.35 & 0.28 & 0.53 \\
\hline Antibiotic of RAUBITSCHEK & 0.21 & 0.41 & 0.40 \\
\hline $\begin{array}{l}\text { Bacillomycin of LANDY } \\
\text { et al. }\end{array}$ & 0.16 & 0.39 & 0.38 \\
\hline Iturin A & 0.35 & 0.28 & 0.53 \\
\hline Mycosubtilin & 0.26 & 0.24 & 0.48 \\
\hline
\end{tabular}

\section{Identification of Iturin A as Active Compound in Bacillomycin B, Bacillomycin $\mathbf{R}$ and Eumycin}

Physicochemical Properties.

Pure antibiotics from bacillomycin B, bacillomycin R and eumycin have the same solubility as iturin A: they are very soluble in methanol and dimethylformamide, slightly soluble or insoluble in 
other organic solvents, chloroform, ethyl ether, acetone, pyridine, etc. The melting points: 177 $179^{\circ} \mathrm{C}$ are identical for iturin A and other antibiotics. PAULY reaction ${ }^{14}$ ) is positive and ninhydrin reaction negative.

\section{Amino Acid Composition.}

Each antibiotic was hydrolyzed in $6 \mathrm{~N} \mathrm{HCl}$ at $150^{\circ} \mathrm{C}, 8$ hours. Hydrolysates were extracted with chloroform, a lipid part and a water-soluble part were obtained. The water phase aminoacids were identified by thin-layer chromatography on cellulose with butanol - acetic acid - water $(65: 10: 25)$ and by paper chromatography with pyridine - tert-amyl alcohol - water (35:35:30). In hydrolysates of all antibiotics aspartic acid, glutamic acid, proline, serine and tyrosine were found. Quantitative analysis gave molar ratios identical to those of iturin A: Asp $, \mathrm{Glu}_{1}, \mathrm{Pro}_{1}, \mathrm{Ser}_{1}, \mathrm{Tyr}_{1}$.

Nature of Lipid Part.

The lipid part was tested by thin-layer chromatography on silica gel 60 with chloroform - methanol water $(65: 25: 4)$. Detection with ninhydrin gave only one spot ( $\mathrm{Rf} 0.63)$ for all antibiotics and for iturin A. Previously, we defined the structure of the lipid part of iturin A which consists of $\beta$ amino acids with 14 and 15 carbon atoms $^{32}$. The lipid part of antibiotics from bacillomycin B, bacillomycin $\mathrm{R}$ and eumycin was studied by gas chromatography of the $\mathrm{N}$-trifluoroacetyl $n$-butyl esters. The chromatograms were very similar to the chromatogram of the derivatives of iturin $A, \beta$ amino acids $C_{14}$ and $C_{15}$ were the major components of the lipid fraction and the ratios are shown in Table 4.

The percentages of $\beta$ amino acids were roughly similar in all the antibiotics with about $40 \sim 50 \%$ of each major compound as components of the lipid part.

Nature of Liposoluble Peptides.

In the previous work on the structure of iturin $\mathrm{A}$ it was demonstrated that a partial hydrolysis $\left(6 \mathrm{~N} \mathrm{HCl}, 105^{\circ} \mathrm{C}, 15\right.$ hours) gave liposoluble peptides which were identified as seryl- $\beta$ amino acids $C_{14}$ and $\mathrm{C}_{15}$. Antibiotics from bacillomycin $\mathrm{B}$, bacillomycin $\mathrm{R}$ and eumycin were hydrolyzed in the same conditions. The lipid moieties were extracted by chloroform and tested by thin-layer chromatography on silica gel 60 with chloroform - methanol - water $(65: 25: 4)$ in comparison with the lipid fraction from iturin A. All the lipid fractions gave a spot, of Rf 0.33 , positive with ninhydrin, which was isolated by scrapping the plate. This compound was dinitrophenylated with 2,4-dinitrofluorobenzene and hydro-

Table 4. Percentages of liposoluble $\beta$-amino acids in the purified antibiotics.

\begin{tabular}{l|c|c|c|c}
\hline$\beta$-Amino acids & $\begin{array}{c}\text { Bacillo- } \\
\text { mycin B }\end{array}$ & $\begin{array}{c}\text { Bacillo- } \\
\text { mycin R }\end{array}$ & Eumycin & Iturin A \\
\hline $\begin{array}{c}\text { 3-Amino 12-me- } \\
\text { thyl tridecanoic } \\
\text { acid }\end{array}$ & 52 & 40 & 50 & 34 \\
$\begin{array}{c}\text { 3-Amino 12-me- } \\
\text { thyl tetrade- } \\
\text { canoic acid }\end{array}$ & 40 & 57 & 44 & 47 \\
$\begin{array}{c}\text { 3-Amino 12-me- } \\
\text { thyl pentade- } \\
\text { canoic acid }\end{array}$ & 2 & - & 1 & 8 \\
$\begin{array}{c}\text { 3-Amino hexade- } \\
\text { canoic acid }\end{array}$ & 5 & 3 & 5 & 8 \\
$\begin{array}{c}\text { 3-Amino 12-me- } \\
\text { thyl hexade- } \\
\text { canoic acid }\end{array}$ & 1 & - & - & 3 \\
\hline
\end{tabular}

Table 5. Antifungal activity of pure antibiotics on Penicillium chrysogenum.

\begin{tabular}{l|c|c}
\hline \multirow{2}{*}{ Antibiotic } & \multicolumn{2}{|c}{ Concentration } \\
\cline { 2 - 3 } & $50 \mu \mathrm{g} / \mathrm{ml}$ & $500 \mu \mathrm{g} / \mathrm{ml}$ \\
\hline Iturin A & 20 & \\
Bacillomycin B & 18 & \\
Bacillomycin R & 20 & \\
Eumycin & 18 & \\
Mycosubtilin & - & 20 \\
\hline
\end{tabular}

Agar plate diffusion method, diameters of the zone of inhibition (in mm). With $200 \mu \mathrm{l}$ of the solution of each antibiotic. 
lyzed by $6 \mathrm{~N} \mathrm{HCl}, 8$ hours at $150^{\circ} \mathrm{C}$. The hydrolysates were analyzed by thin-layer chromatography on silica gel 60 with chloroform - methanol - water (65:25:4). Two compounds were identified, DNP-Ser $(\operatorname{Rf} 0.20)$ and $\beta$-amino acids ( Rf 0.63).

Partial hydrolysis of the tested antibiotics and of iturin A gave identical lipid fractions identified as seryl- $\beta$ amino acids.

Antifungal Activities.

Purified antibiotics from bacillomycin B, bacillomycin R, eumycin, were tested for their antifungal activity in comparison with iturin $\mathrm{A}$ and mycosubtilin.

As shown in Table 5 the antifungal activity, tested on Penicillium chrysogenum, of iturin A and of pure antibiotics isolated from bacillomycin $\mathrm{B}$, bacillomycin $\mathrm{R}$ and eumycin preparations is identical.

\section{Conclusions}

Several antibiotic preparations have been isolated from various strains of Bacillus subtilis. It would be possible that an unique active compound was responsible for the antifungal activity of some of these preparations. Two compounds, iturin A and mycosubtilin, have been studied more exhaustively and their structures have been determined ${ }^{4,5,7)}$. The purification of the active compound from 5 antibiotic preparations has shown the presence of iturin $\mathrm{A}$ in 3 preparations: bacillomycin $\mathrm{B}$, bacillomycin R and eumycin. Two preparations: the antibiotic of RAUBITSCHEK, and the bacillomycin of LANDY et al. are different from iturin A and mycosubtilin. However, all these antibiotics have a common structural characteristic, they are peptidolipids and the lipid moiety consists of $\beta$ amino acids with $14 \sim 17$ carbon atoms. One can suppose that $\beta$ amino acids are common precursors in the biosynthesis of all peptidolipid antibiotics from Bacillus subtilis and the addition of $\alpha$ amino acids to give the peptide part, and to present some variations with particular producing strains of bacillus.

\section{Material and Methods}

Antibiotics and producing strains.

We are very grateful to Dr. G. H. WARREN of the Wyeth Institute of Applied Biochemistry, 2409 Walnut Street, Philadelphia 3, Penn., U.S.A. for a sample of bacillomycin B and to Dr. H. B. WooDRUFF of Merck Co., Rahway, N. J., U.S.A. for a sample of mycosubtilin.

The other antibiotics investigated here have been prepared in the pilot plant of the C.N.P.E.M. with producing strains kindly supplied for eumycin: by Dr. K. L. Burdon of Baylor University, College of Medicine, Texas Medical Center, Houston, Texas, U.S.A.; for bacillomycin R by Dr. A. PINSKY of the Dairy Research Laboratory, Agricultural Research Station, Rehovot, Israel; for bacillomycin B by Dr. L. Shibasaki of Department of Fermentation Technology, Faculty of Engineering, Osaka University, Japan; and for the antibiotic of RAUBITSCHEK by Dr. F. RAUBITSCHEK of Rothschild Hadassah Medical Organization, Jerusalem, Israel.

Production and preliminary purification.

The composition of the medium was ( $\mathrm{g} /$ liter of water): glucose 10 , brown sugar 10 , peptone 15 , $\mathrm{Na}_{2} \mathrm{HPO}_{4} 0.2$ and $\mathrm{NaCl}$ 0.2. Submerged aerated culture of the producing strain was grown in 1-liter Erlenmeyer flasks containing $250 \mathrm{ml}$ of medium on a shaker rotating at 100 r.p.m., with a $2^{\prime \prime}$ stroke, at $30^{\circ} \mathrm{C}$ for 48 hours. A part $(2 \%)$ of this culture was used to inoculate a 500 -liter fermenter. Submerged culture was performed at $30^{\circ} \mathrm{C}$, under stirring(120 r.p.m.) and aeration(500-liter air per minute). Silicone emulsion was used as antifoam agent. The antibiotic content reached a maximum after $2 \sim 3$ days.

The cooled broth was treated with $2 \%$ of filter aid(Celite) and filtered on a filter press in order to eliminate most of the bacteria. Filtrate was adjusted to about $\mathrm{pH} 3.0$ with concentrated $\mathrm{HCl}$. 
The precipitate obtained was collected by centrifugation (Sharpless 5A) and extracted three times with a mixture of $n$-butanol-acetone $(20: 1)$. The solid residue separated by centrifugation was discarded. The extract was neutralized with $\mathrm{CaCO}_{3}$ powder and filtered. The filtrate was concentrated under vacuum at $30 \sim 40^{\circ} \mathrm{C}$ to one-fifth of its volume. The concentrated solution was poured into ten volume of a mixture of acetone - ethyl ether (1:2). A yellow-brown precipitate of crude antibiotic was obtained and dried under vacuum. The yield, varying from one strain to another, was about $100 \mathrm{~g}$ of product.

A preliminary purification was realized by chromatography on a neutral alumina column (diameter $8 \mathrm{~cm}$, height $15 \mathrm{~cm})$. The elution was obtained with a mixture (3 liters) of acetone - water $(2: 1)$. The eluate was distilled under vacuum in order to eliminate the acetone and the aqueous solution was lyophilized. The yield was about $20 \mathrm{~g}$ of product.

Antibiotic activity.

Antibacterial and antifungal activities were tested either by a cylinder agar plate diffusion method or by a serial tube dilution method. In the first method the appropriate solution of the substance to be tested was put in small cylinders (diameter $6 \mathrm{~mm}$, height $8 \mathrm{~mm}$ ) deposited on agar seeded with Penicillium chrysogenum. The diameter of the zone of inhibition was measured after 48 hours of incubation at $28^{\circ} \mathrm{C}$.

In the second method a serial twofold tube dilution of the antibiotic in nutrient broth was prepared. Each tube was inoculated with a drop of a one night culture of sensitive microorganism diluted 500 times. The minimal inhibitory concentration (MIC) was determined after 48 hours of incubation.

Purification and isolation of pure antibiotics.

After elimination of pigments by precipitation with acetone, the antibiotic preparations were purified by column chromatography on Sephadex LH 20 (200 mg for $40 \mathrm{~g}$ of Sephadex). Elution was performed with hexane - chloroform - methanol $(25: 45: 10)$. The fractions were examined by thinlayer chromatography on silica gel 60 with chloroform - methanol - water $(65: 25: 4)$. Their antifungal activity was tested on Penicillium chrysogenum.

Antifungal fractions were further purified by column chromatography on silicic acid Bio Sil HA 325 mesh. After elution with chloroform - methanol - water $(65: 25: 4)$, eluates were tested by thinlayer chromatography in the same solvent and detected with PAULY reagent ${ }^{14}$. Their identification was made by comparing their Rf with those of iturin $\mathrm{A}$ and mycosubtilin.

Some fractions were further purified by a second column chromatography on silicic acid.

Hydrolysis

Total hydrolysis of purified antibiotics was performed with $6 \mathrm{~N} \mathrm{HCl}$, in sealed tubes, at $150^{\circ} \mathrm{C}$ for 8 hours, partial hydrolysis of purified antibiotics was performed with $6 \mathrm{~N} \mathrm{HCl}$, in sealed tubes at $105^{\circ} \mathrm{C}$ for 15 hours.

After total and partial hydrolysis liposoluble and hydrosoluble moieties were obtained. The liposoluble part was extracted with chloroform and the hydrosoluble part was evaporated to dryness in vacuo.

Analysis of amino acids

The quantitative amino acid analyses were carried out with a Technicon automatic analyser following the procedure of Spackman et al. ${ }^{15)}$ modified by Piez and Morris ${ }^{16)}$.

Identification of the lipid part.

The N-trifluoroacetyl $n$-butyl esters derivatives were obtained by the method of RoACH and GeHRKE $^{17)}$. The liposoluble moiety was treated with $\mathrm{HCl}$ - butanol. After elimination of butanol by distillation, the residue was dissolved in methylene chloride - trifluoroacetic anhydride (4:1) and the reaction was carried out at $150^{\circ} \mathrm{C}$ for 15 minutes in a sealed tube.

These derivatives were studied by gas chromatographic analysis in a Fractovap GT 200 apparatus with ethyleneglycoladipate $0.65 \%$ on Chromosorb W with temperature programming from $80^{\circ} \mathrm{C}$ to $215^{\circ} \mathrm{C}$. 


\section{References}

1) Asselineau, J. \& J. P. Zalta: Les Antibiotiques, Herman, Paris, p. 132, 1973

2) Delcambe, L.: Iturine. I. Préparation, purification et poids moléculaire. Bull. Soc. Chim. Belg. 74: 315 328, 1965

3) Peypoux, F.; M. Guinand, G. Michel, L. Delcambe, B. C. Das, P. Varenne \& E. Lederer: Isolement de l'acide 3-amino 12 - méthyl - tétradécanoique et de l'acide 3-amino-12-méthyl-tridécanoique à partir de l'iturine, antibiotique de Bacillus subtilis. Tetrahedron 29; 3455 3459, 1973

4) Peypoux, F.; G. Michel, B. C. Das \& E. Lederer: Application de la spectrométrie de masse à l'étude de l'iturine, antibiotique de Bacillus subtilis. L'Actualité Chimique 7: 70, 1974

5) Peypoux, F.; M. Guinand, G. Michel, L. Delcambe, B. C. Das \& E. Lederer: Structure of iturine, a lipopeptide antibiotic from Bacillus subtilis. Biochemistry, in press.

6) Walton, R. B. \& H. B. WoodrufF: A crystalline antifungal agent, mycosubtiline, isolated from subtilin broth. J. Clin. Invest. 28: 924 926, 1949

7) Peypoux, F.; G. Michel \& L. Delcambe: Structure de la mycosubtiline, antibiotique isolé de Bacillus subtilis. Eur. J. Biochem. 63: 391 398, 1976

8) Sharon, N.; A. Pinsky, R. Turner-Graff \& J. Babad: Classification of the antifungal antibiotics from Bacillus subtilis. Nature 174: 1190 1191, 1954

9) Shibasaki, I. \& G. Terui: Antifungal substances produced by a strain of Bacillus subtilis. J. Ferment. Technol. 32: 115 118, 1954

10) Babad, J.: A. Pinsky, R. Turner-Graff \& N. Sharon: An antifungal polypeptide produced by Bacillus subtilis. Nature 170: 618 619, 1952

11) Johson, E. A. \& K. L. Burdon: Eumycin, a new antibiotic active against pathogenic fungi and higher bacteria including bacilli of tuberculosis and diphteria. J. Bacteriol. 51: 591, 1946

12) RaubitscheK, F. \& A. Dostsowsky: An antibiotic active against dermatophytes derived from Bacillus subtilis. Dermatologica 100: 45 49, 1950

13) Landy, M.; G. H. Warren, S. B. Rosenman \& L. G. Colio: Bacillomycin: an antibiotic from Bacillus subtilis active against pathogenic fungi. Proc. Soc. Exp. Biol. \& Med. 67: 539 541, 1948

14) Jutisz, M.: Chromatographie en chimie organique et biologique. Vol. II, p. 373, Masson, Paris, 1960

15) Spackman, D. H.; W. H. Stein \& S. Moore: Automatic recording apparatus for use in the chromatography of aminoacids. Anal. Chem. 30: 1190 1206, 1958

16) Piez, K. A. \& L. Morris: A modified procedure for the automatic analysis of aminoacids. Anal. Biochem. 1: 187 201, 1960

17) ROACH, D. \& C. W. GeHRKE: Direct esterification of the protein aminoacids. Gas-liquid chromatography of N - TFA $n$-butyl - esters. J. Chromatogr. 44: 269 278, 1969 